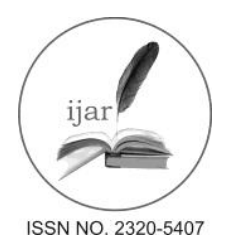

\author{
Journal homepage: http://www.journalijar.com

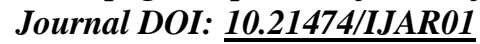

INTERNATIONAL JOURNAL

OF ADVANCED RESEARCH

RESEARCH ARTICLE

\title{
SYNTHESIS, SPECTROSCOPY, STRUCTURAL AND BIOLOGICAL STUDIES OF HG(II), MN(II) AND CO(II) COMPLEXES OF COUMARIN DERIVATIVES.
}

\author{
Rania Zaky*, Yasmeen G. Abou El-Reash, Ahmed Fekri, Hany M. Youssef, Abdulrahman S. Noori. \\ Department of Chemistry, Faculty of Science, Mansoura University, Mansoura, Egypt.
}

\section{Manuscript Info}

Manuscript History:

Received: 14 April 2016

Final Accepted: 19 May 2016

Published Online: June 2016

Key words:

Hydrazone complexes, DFT, Ion-

flotation, Anti-oxidant.

\section{Abstract}

A series of $\mathrm{Hg}(\mathrm{II}), \mathrm{Mn}(\mathrm{II})$ and $\mathrm{Co}(\mathrm{II})$ complexes with 3-(2-(2-oxo- $2 \mathrm{H}-$ chromene-3-carbonyl)hydrazono)-N-(pyridin-2-yl)butanamide $\left(\mathrm{H}_{2} \mathrm{~L}\right)$ were synthesised. The synthesized compounds were deduced by various spectroscopic techniques. The geometry of isolated complexes was estimated by using the DFT theory. Also, $\mathrm{Pb}$ (II) and $\mathrm{Cd}(\mathrm{II})$ were separated by means of flotation technique. Moreover, cytotoxic, antimicrobial and anti-oxidant activities of the synthesized compounds were examined.

*Corresponding Author

Rania Zaky.

Copy Right, IJAR, 2016,. All rights reserved.

\section{Introduction:-}

Coumarin was used in a wide-ranging in the pharmacological manufacturing as a pioneer reagent in the production of some synthetic anticoagulant drugs such as dicoumarol. Although, coumarin alone has not any anticoagulant properties it was converted into the natural anticoagulant dicoumarol via a numeral of fungi species. Dicoumarol material was accountable for sweet clover disease in the cattle eating moldy sweet clover silage [1, 2]. Also, coumarin has anti-fungal, anti-bacterial and anti-tumor activities and properties [3, 4].

Coumarin derivatives are actual good complexing agent since it has powerful binding sites for complexation with transition metal ions. This complexes were played a significant role in pharmaceuticals chemistry as well as with coordination chemistry [5]. Moreover, coumarin derivatives used in analytical chemistry as a choosy metal extracting agents. Wherever, there are several techniques such as column extraction, ion-flotation, co-precipitation, ionselective electrode, cloud point extraction, solid phase extraction and liquid-liquid extraction were used in separation and preconcentration of some trace metal [6-10]. The ion-flotation method attracted a significant attention of researchers because of it was considered an economy, simple, efficient and speedy quantitative process [11-15].

In continuously of our work, $\mathrm{Hg}(\mathrm{II}), \mathrm{Mn}(\mathrm{II})$ and $\mathrm{Co}(\mathrm{II})$ complexes of 3-(2-(2-oxo-2H-chromene-3carbonyl)hydrazono)-N-(pyridin-2-yl)butanamide were prepared and characterized [16-20]. The manner of complexation was interpreted via numerous spectroscopic and physical methods. Also, the biological activity of the isolated compounds were tested.

\section{Experimental:-}

Materials and reagents:-

All materials and reagents used are pure (Merck, Sigma or Aldrich). They included:

a. Organic substance; 2-oxo-2H-chromene-3-carbohydrazide and 3-oxo-N-(pyridin-2-yl)butanamide, HOL (oleic acid).

b. Metal salts; $\left[\mathrm{Co}\left(\mathrm{CH}_{3} \mathrm{COO}\right)_{2}\right] \cdot 4 \mathrm{H}_{2} \mathrm{O},\left[\mathrm{CdCl}_{2}\right] \cdot 2 \mathrm{H}_{2} \mathrm{O}, \mathrm{MnCl}_{2} \cdot 2 \mathrm{H}_{2} \mathrm{O}, \mathrm{HgCl}_{2}$ and $\mathrm{Pb}\left(\mathrm{NO}_{3}\right)_{2}$.

c. Solvents; Absolute ethyl alcohol, dimethyl formamide and diethyl ether. 


\section{Solutions:-}

A stock solution of: (a) HOL (oleic acid) $\left(6.36 \times 10^{-2}\right.$ mol. $\left.\mathrm{L}^{-1}\right)$ were prepared by dissolving $20 \mathrm{~mL}$ in one liter of kerosene; (b) $\mathrm{CdCl}_{2} \cdot \mathrm{H}_{2} \mathrm{O}$ and $\mathrm{Pb}\left(\mathrm{NO}_{3}\right)_{2}\left(1 \times 10^{-2}\right.$ mol. $\left.\mathrm{L}^{-1}\right)$ were prepared in $100 \mathrm{ml}$ bidistilled water; (c) $1 \times 10^{-2}$ mol. $\mathrm{L}^{-1}$ of ligand was prepared in $100 \mathrm{ml}$ absolute ethanol.

Instrumentation:-

\begin{tabular}{|c|c|}
\hline Purpose & Apparatus \\
\hline - $\quad$ Detect the infra-red spectrum & $\begin{array}{l}\text { The FTIR spectrophotometer Mattson 5000, Madison, USA } \\
\left(\text { range } 4,000-400 \mathrm{~cm}^{-1}\right)\end{array}$ \\
\hline Record the ${ }^{1} \mathrm{H}$ NMR spectrum & $\begin{array}{l}\text { The EM-390 (200 MHz) on a Varian Mercury-300 instrument } \\
\text { (Switzerland) }\end{array}$ \\
\hline Record the MS & The Mattson 5000 FTIR spectrophotometer \\
\hline $\mathrm{pH}$ measurements & The pH meter "Hanna instrument 8519 digital" \\
\hline $\begin{array}{l}\text { Evaluate values of magnetic moment at } \\
\text { RT }\left(25 \pm 1^{\circ} \mathrm{C}\right)\end{array}$ & $\begin{array}{l}\text { The magnetic susceptibility balance "Johnson Matthey Wayne, } \\
\text { Pennsylvania, USA" }\end{array}$ \\
\hline - $\quad$ Record the UV-vis. & $\begin{array}{l}\text { The spectrophotometer Shimadzu UV } 240 \text { (P/N 204-58000) } \\
\text { (USA) in the range } 200-900 \mathrm{~nm}\end{array}$ \\
\hline Determinations the analytes concentration & $\begin{array}{lccc}\text { GBC, Sensaa } & \text { Series Atomic } & \text { Absorption } & \text { Spectrometry } \\
\text { (computerized AAS) with air-acetylene flame }\end{array}$ \\
\hline Flotation and separation detection & $\begin{array}{l}\text { Two types of cells which are cylindrical tube of }(29,45) \mathrm{cm} \\
\text { length and }(1.2,6) \mathrm{cm} \text { inner diameter with a stopper at the top }\end{array}$ \\
\hline Determination the $\%$ of $(\mathrm{C}, \mathrm{H}$ and $\mathrm{N})$ & The "Perkin-Elmer 2400 Series II Analyzer" \\
\hline
\end{tabular}

Synthesis of $\mathrm{H}_{2} \mathrm{~L}$ :-

The $\mathrm{H}_{2} \mathrm{~L}$ was produced by adding of 2-oxo- $2 \mathrm{H}$-chromene-3-carbohydrazide (2.04gm) to 3-oxo- $\mathrm{N}$-(pyridin-2yl)butanamide $(1.78 \mathrm{gm})$ in $30 \mathrm{ml}$ ethanol in existence of glacial acid $(1 \mathrm{ml})$. The reaction mixture were stirred for 4 $\mathrm{h}$ (Scheme 1). The formed precipitate were filtrated and recrystallized from absolute alcohol.

Scheme 1:- The outline of the synthesis of ligand $\left(\mathrm{H}_{2} \mathrm{~L}\right)$ and its metal complexes.

\section{Synthesis of metal complexes:-}


The isolated solid complexes were synthesized by addition equimolar amounts of ligand $\left(\mathrm{H}_{2} \mathrm{~L}\right)$ with hot ethanolic and/or aqueous solution of chloride salt of $\mathrm{Hg}$ (II) and $\mathrm{Mn}$ (II); acetate salt of $\mathrm{Co}$ (II). The mixture was heated on a water bath for $3 \mathrm{~h}$. The formed precipitate was filtered off, washed away with hot ethanol. The physical and analytical properties were recorded in Table 1.

Table 1:- Elemental analysis and physical data of $\mathrm{H}_{2} \mathrm{~L}$ and its metal complexes.

\begin{tabular}{|c|c|c|c|c|c|c|c|c|c|c|c|}
\hline & No. & Compound & Formula & M.Wt. & Color & Yield & m.p. & \multicolumn{4}{|c|}{ Found (Calculated) } \\
\hline & & & & & & & $\mathrm{C}$ & $\mathrm{H}$ & $\mathrm{N}$ & $\mathrm{M}$ & $\mathrm{Cl}$ \\
\hline 1 & $\mathrm{H}_{2} \mathrm{~L}$ & $\mathrm{C}_{19} \mathrm{H}_{16} \mathrm{O}_{4} \mathrm{~N}_{4}$ & 364.74 & $\begin{array}{c}\text { Pale } \\
\text { Yellow }\end{array}$ & 80 & 270 & $\begin{array}{c}62.51 \\
(62.57) \\
\end{array}$ & $\begin{array}{c}4.39 \\
(4.42) \\
\end{array}$ & $\begin{array}{c}15.91 \\
(15.46) \\
\end{array}$ & - & - \\
\hline 3 & {$\left[\mathrm{Mn}\left(\mathrm{H}_{2} \mathrm{~L}\right)\left(\mathrm{H}_{2} \mathrm{O}\right) \mathrm{Cl}_{2}\right]$} & $\mathrm{MnC}_{19} \mathrm{H}_{18} \mathrm{~N}_{4} \mathrm{O}_{5} \mathrm{Cl}_{2}$ & 508.694 & buff & 70 & $300>$ & $\begin{array}{c}44.81 \\
(44.86) \\
\end{array}$ & $\begin{array}{c}3.59 \\
(3.57) \\
\end{array}$ & $\begin{array}{r}11.02 \\
(11.13) \\
\end{array}$ & $\begin{array}{c}10.82 \\
(10.79) \\
\end{array}$ & $\begin{array}{c}13.93 \\
(13.96) \\
\end{array}$ \\
\hline
\end{tabular}

Molecular modeling:-

The DFT method used to predict the geometry of the isolated complexes via the GAUSSIAN 09 program package by using DMOL3 program in Materials Studio package [21, 22]. The DNP basis sets are of analogous class to 6-31G Gaussian basis sets [23]. The DNP basis sets more accurate than Gaussian basis sets of the identical size [24]. The best brilliant exchange-correlation functional was measured based on the GGA and RPBE functional [25, 26].

Antibacterial and antifungal activities in terms of Minimum inhibitory concentration:-

* The MIC of the synthesized compounds was determined by applying agar streak dilution method [27].

* The strains involved Staphylococcus aureus and Bacillus subtilis as Gram (+)ve bacteria; Escherichia coli and Pseudomonas aeuroginosa as Gram (-)ve bacteria; Candida albicans and Aspergillus flavus as fungi

* For anti-bacterial the Ciprofloxacin $(100 \mu \mathrm{g} / \mathrm{ml})$ used as standard, but Fluconazole (100 $\mu \mathrm{g} / \mathrm{ml}) \mathrm{was}$ used as standard for anti-fungal.

* A stock solution $(100 \mu \mathrm{g} / \mathrm{ml})$ of the examined compounds in DMSO was prepared and then incorporated in specified quantity of molten sterile.

* A certain amount of the medium containing tested compound was decanted into a Petri dish to reach a depth of 3-4 $\mathrm{mm}$ at $40-50{ }^{\circ} \mathrm{C}$ and then, permitted to solidify.

* The micro-organism suspension was set to take about $105 \mathrm{cfu} / \mathrm{ml}$ and smeared to plates with diluted compounds in DMSO to be tested and then, incubated for $24-48 \mathrm{~h}$ at $37^{\circ} \mathrm{C}$.

* The MIC was measured until the lowest concentration of the test substance showing no visible growth of bacteria or fungi on the plate.

Anti-oxidant activity screening assay - ABTS method:-

* In ABTS method; (2 ml, $60 \mathrm{mM})$ of ABTS + (3 ml, $25 \mathrm{mg} / \mathrm{ml}) \mathrm{MnO}_{2}+(5 \mathrm{ml}, \mathrm{pH} 7,0.1 \mathrm{M})$ phosphate buffer was added to investigated compounds.

* The absorbance was measured at $\lambda 734 \mathrm{~nm}$ for the resultant green-blue solution after the mix was shaken, centrifuged and filtered.

* After that, $(50 \mathrm{ml}, 2 \mathrm{mM})$ the investigated compounds was added to $(1: 1)$ methanol/phosphate buffer in spectroscopic grade.

* The absorbance was detected, and the intensity of color reduction was supposed as inhibition \%. The L-ascorbic acid (standard antioxidant) used as a $(+)$ control.

* Blank sample was run without ABTS and using methanol/phosphate buffer (1:1) in place of tested compounds. However, the ABTS and methanol/phosphate buffer (1:1) used as a negative control [28, 29].

$$
\mathrm{I} \%=\left(\mathrm{A}_{\text {blank }}-\mathrm{A}_{\text {sample }}\right) /\left(\mathrm{A}_{\text {blank }}\right) \times 100
$$

Where $A_{\text {blank }}$ is the absorbance of the control reaction,

Asample is the absorbance in the existence of the testers or standards. 


\section{Anti-oxidant screening assay for erythrocyte hemolysis:-}

Erythrocytes were gotten from the buffy coat and plasma then, the blood was acquired by cardiac puncture from rats and then collected in heparinized tubes. After that, the mix was washed three times with 10 volumes of $0.15 \mathrm{M}$ $\mathrm{NaCl}$, then, it centrifuged for $10 \mathrm{~min}$ at $2500 \mathrm{rpm}$ to attain a regularly packed cell preparation. In this examine system erythrocyte hemolysis was intervened by peroxyl radicals [30]. To the same volume of $200 \mathrm{mM}$ of AAPH solution in PBS, a 10\% of erythrocytes suspension in pH 7.4 phosphate-buffered saline (PBS) was added to the investigated samples at different concentrations. Then the mix was shacked and incubated at $37{ }^{\circ} \mathrm{C}$ for 1 hour. Next, mixture was detached, diluted with 8 volumes of PBS and centrifuged at $2500 \mathrm{rpm}$ for $10 \mathrm{~min}$. The absorbance (A) of the supernatant was detected at $540 \mathrm{~nm}$. Likewise, the mixture was conserved with 8 volumes of distilled water to attain complete hemolysis then, at $540 \mathrm{~nm}$ the absorbance (B) of the supernatant attained after centrifugation was determined. The $\%$ hemolysis was measured by the following equation:

$$
\% \text { hemolysis }=(1-\mathrm{A} / \mathrm{B}) \times 100 \%
$$

\section{Cell proliferation assay:-}

* By MTT colorimetric assay the compounds inhibitory effects on cell growth was determine $[31,32]$.

* The 100 units $/ \mathrm{ml}$ penicillin and $100 \mu \mathrm{g} / \mathrm{ml}$ streptomycin are the antibiotics used under $5 \% \mathrm{CO}_{2}$ at $37{ }^{\circ} \mathrm{C}$ for $48 \mathrm{~h}$ incubator and seeds in a 96-well plate with density $1.0 \times 10^{4}$ cells/well $[33,34]$.

* Then the incubated cells were conserved with dissimilar concentration of compounds for $24 \mathrm{~h}$. next, $24 \mathrm{~h}$ of medicine action, $20 \mu \mathrm{l}$ of MTT solution at $5 \mathrm{mg} / \mathrm{ml}$ was added and incubated for $4 \mathrm{~h}$.

* After that $100 \mu \mathrm{l}$ of DMSO was added to each well to dissolve the purple formazan. The colorimetric test was determined by using a plate reader (EXL 800, USA) at absorbance of $570 \mathrm{~nm}$.

* By using the following equation the $\%$ of relative cell viability was measured:

A570 of treated samples/A570 of untreated sample x 100.

\section{Flotation-separation procedure:-}

A definite amount of $\mathrm{Cd}^{2+}$ and $\mathrm{Pb}^{2+}$ solutions was added to the dissolved ligand. The $\mathrm{pH}$ of earlier mixture was adjusted with sodium hydroxide and/or nitric acid to reach the preferred concentration. Then, the distilled water was added to $10 \mathrm{~mL}$ with in the flotation cell. To confirm complete complexation, the cell was shacked well for $2 \mathrm{~min}$ and then $2 \mathrm{~mL}$ of oleic acid were added. After that, the cell was inverted upside down 20 times by hand and left 5 min standing for comprehensive flotation. Lastly, the concentration of $\mathrm{Cd}^{2+}$ or $\mathrm{Pb}^{2+}$ ions remained in the mother liquor was investigated via AAS. The floatability $\%$ of $\mathrm{Cd}^{2+}$ or $\mathrm{Pb}^{2+}$ ions was determined by using the following equation:

$$
\mathrm{F} \%=\left(\mathrm{C}_{\mathrm{i}}-\mathrm{C}_{\mathrm{f}}\right) / \mathrm{Ci} \times 100
$$

Where: $\mathrm{C}_{\mathrm{i}}$ is initial concentrations; $\mathrm{C}_{\mathrm{f}}$ is the final concentrations, of $\mathrm{Cd}^{2+}$ or $\mathrm{Pb}^{2+}$ ions in the mother liquor, respectively.

\section{Results and Discussion:- IR and ${ }^{1} \mathrm{H}$ NMR spectra:-}

In the IR spectrum of $\mathrm{H}_{2} \mathrm{~L}$ (Table 2), the bands observed at 1603, 689, 1750, 1655, 1675, 3285, 3180 and $3051 \mathrm{~cm}^{-}$ ${ }^{1}$ are attributed to $v(\mathrm{C}=\mathrm{N}), \mathrm{v}(\mathrm{C}=\mathrm{N})_{\mathrm{py}}, \mathrm{v}(\mathrm{C}=\mathrm{O})_{1}, \mathrm{v}(\mathrm{C}=\mathrm{O})_{2}, \mathrm{v}(\mathrm{C}=\mathrm{O})_{3}, \mathrm{v}(\mathrm{NH})_{1}, \mathrm{v}(\mathrm{NH})_{2}, v\left(\mathrm{CH}_{2}\right)$ [35-37]. Also, in ${ }^{1} \mathrm{H}$ NMR spectrum of $\mathrm{H}_{2} \mathrm{~L}$ there are two signals observed at 11.27 and $12.23 \mathrm{ppm}$ ascribed to the $(\mathrm{NH})_{1}$ and $(\mathrm{NH})_{2}$ protons, respectively (Scheme 2). There are multiplet signals were showed in $6.60-8.04 \mathrm{ppm}$ region related to the $\mathrm{N}=\mathrm{CH}-$ and aromatic protons. There is a sharp signal correlated to protons of $\left(-\mathrm{CH}_{2}\right)$ at $3.46 \mathrm{ppm}$.

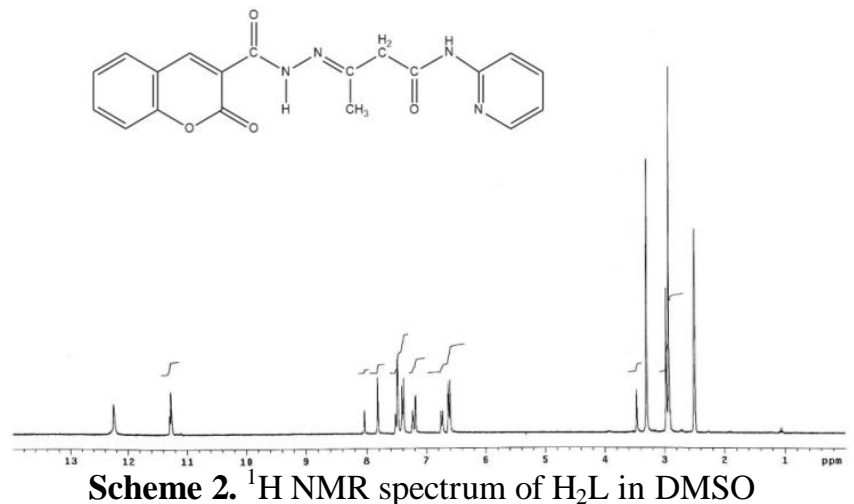


In $\left[\mathrm{Hg}\left(\mathrm{H}_{2} \mathrm{~L}\right)\left(\mathrm{H}_{2} \mathrm{O}\right)_{2} \mathrm{Cl}_{2}\right]$ complex the ligand behaved in a neutral bidentate manner coordinating via carbonyl oxygen $(\mathrm{C}=\mathrm{O})_{3}$ and azomethine nitrogen $(\mathrm{C}=\mathrm{N})$. This mode of coordination is suggested by the negative shift of both $v(\mathrm{C}=\mathrm{O})_{3}$ and $v(\mathrm{C}=\mathrm{N})$ the existence of new bands at 565 and $476 \mathrm{~cm}^{-1}$ which ascribed to $(\mathrm{Hg}-\mathrm{O})$ and $(\mathrm{Hg}-\mathrm{N})[38]$, respectively.

Also, in the IR spectrum of $\left[\mathrm{Mn}\left(\mathrm{H}_{2} \mathrm{~L}\right)\left(\mathrm{H}_{2} \mathrm{O}\right) \mathrm{Cl}_{2}\right]$ complex, $\mathrm{H}_{2} \mathrm{~L}$ behaved as a neutral tridentate ligand chelating via $(\mathrm{C}=\mathrm{N}),(\mathrm{C}=\mathrm{O})_{2}$ and $(\mathrm{C}=\mathrm{O})_{3}$. This mode of complexation was supported by the negative shift of $v(\mathrm{C}=\mathrm{N}), v(\mathrm{C}=\mathrm{O})_{2}$ and $v(\mathrm{C}=\mathrm{O})_{3}$. The appearance of new bands at the 563 and $467 \mathrm{~cm}^{-1}$ that ascribed to $v(\mathrm{Mn}-\mathrm{O})$ and $v(\mathrm{Mn}-\mathrm{N})[38]$, respectively.

Lastly, in $\left[\mathrm{Co}(\mathrm{HL})(\mathrm{OAc})\left(\mathrm{H}_{2} \mathrm{O}\right)\right] \cdot 2 \mathrm{H}_{2} \mathrm{O}$ complex, the ligand behaved as a mononegative tridentate ligand coordinating via $(\mathrm{C}=\mathrm{N})_{\mathrm{py}},(\mathrm{C}=\mathrm{N})$ and $(\mathrm{C}=\mathrm{O})_{3}$. This manner of complexation is suggested by the absences of $(\mathrm{C}=\mathrm{O})_{3}$ and $\left(\mathrm{NH}_{2}\right)$, with immediate appearance of new bands at 1609 and 1275 attributable to $\left(\mathrm{C}=\mathrm{N}^{*}\right)$ and $(\mathrm{C}-\mathrm{O})$ enolic, respectively [39]. The appearance of new bands at 554 and $470 \mathrm{~cm}^{-1}$ which may be attributed to (Co-O) and (Co-N) [38], respectively.

Table 2. Most important IR spectral bands of $\mathrm{H}_{2} \mathrm{~L}$ and its metal complexes

\begin{tabular}{|l|c|c|c|c|c|c|c|c|c|c|c|c|}
\hline Compound & $v(\mathrm{NH})_{1}$ & $v(\mathrm{NH})_{2}$ & $v\left(\mathrm{CH}_{2}\right)$ & $v(\mathrm{C}=\mathrm{O})_{1}$ & $v(\mathrm{C}=\mathrm{O})_{2}$ & $v(\mathrm{C}=\mathrm{O})_{3}$ & $v(\mathrm{C}=\mathrm{N})$ & $v(\mathrm{C}=\mathrm{N})_{\mathrm{py}}$ & $v\left(\mathrm{C}=\mathrm{N}^{*}\right)$ & $v(\mathrm{C}-\mathrm{O})$ & $v(\mathrm{M}-\mathrm{O})$ & $v(\mathrm{M}-\mathrm{N})$ \\
\hline 1 & 3285 & 3180 & 3051 & 1750 & 1655 & 1675 & 1603 & 689 & - & - & - & - \\
\hline 2 & 3314 & 3189 & 3051 & 1752 & 1660 & 1649 & 1597 & 662 & - & - & 565 & 476 \\
\hline 3 & 3285 & 3184 & 3047 & 1750 & 1643 & 1638 & 1592 & 681 & - & - & 563 & 467 \\
\hline 4 & 3263 & - & 3067 & 1752 & 1652 & - & 1575 & 754 & 1609 & 1275 & 554 & 470 \\
\hline
\end{tabular}

Magnetic moments and electronic spectra:-

In $\left[\mathrm{Co}(\mathrm{HL})(\mathrm{OAc})\left(\mathrm{H}_{2} \mathrm{O}\right)\right] \cdot 2 \mathrm{H}_{2} \mathrm{O}$ electronic spectrum there are two bands at 17857 and $14084 \mathrm{~cm}^{-1}$ attributed to ${ }^{4} \mathrm{~T}_{1 \mathrm{~g}} \rightarrow{ }^{4} \mathrm{~A}_{2 \mathrm{~g}}(\mathrm{~F})$ and ${ }^{4} \mathrm{~T}_{1 \mathrm{~g}} \rightarrow{ }^{4} \mathrm{~T}_{1 \mathrm{~g}}(\mathrm{P})$ transitions, respectively, in an octahedral configuration [40]. The calculated values of $\mathrm{Dq}=743, \mathrm{~B}=825, \beta=0.85$ and $\mho_{2} / \mho_{1}=2.15$ are in good agreement with those stated for octahedral Cobalt (II) complexes. The position of $\mho_{1}=6547 \mathrm{~cm}^{-1}$ is calculated theoretically [40]. Moreover, the value of magnetic moment that equal to 5.1 BM is consistent with octahedral geometry around the Cobalt (II) ion.

\section{Geometry optimization with DFT method:-}

The geometry of new molecular compounds resulting from the interaction between the $\mathrm{H}_{2} \mathrm{~L}$ and several metal cations can be predicted by using DFT method. The molecular structure beside with atom numbering of $\mathrm{H}_{2} \mathrm{~L}$ and its metal complexes were presented in Structure 1.

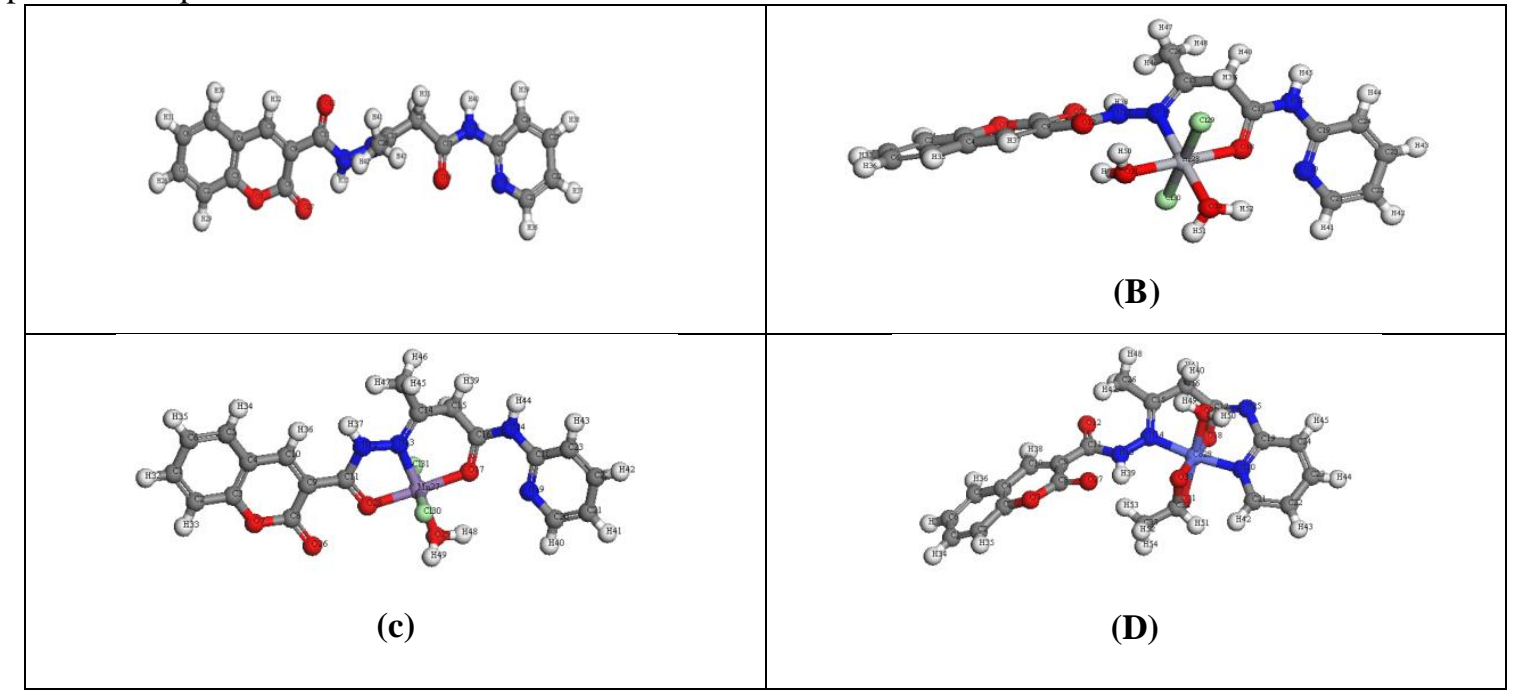

Structure 1. Molecular modeling of (A) $\mathrm{H}_{2} \mathrm{~L}$, (B) $\left[\mathrm{Hg}\left(\mathrm{H}_{2} \mathrm{~L}\right)\left(\mathrm{H}_{2} \mathrm{O}\right)_{2} \mathrm{Cl}_{2}\right]$, (c) $\left[\mathrm{Mn}\left(\mathrm{H}_{2} \mathrm{~L}\right)\left(\mathrm{H}_{2} \mathrm{O}\right) \mathrm{Cl}_{2}\right]$, (D) $\left[\mathrm{Co}(\mathrm{HL})(\mathrm{OAc})\left(\mathrm{H}_{2} \mathrm{O}\right)\right] \cdot 2 \mathrm{H}_{2} \mathrm{O}$ 


\section{Molecular parameters:-}

The Quantum chemical parameters such as $\mathrm{E}_{\text {Hомо }}$ and $\mathrm{E}_{\mathrm{LUmO}}$ of prepared compounds were estimated. Moreover, dipole moment, total energy and binding energy were calculated as shown in Table 3. From the outcome data we can assumed that:

Table 3:- The molecular parameters of the ligand and its complexes.

\begin{tabular}{|c|l|l|l|l|c|}
\hline Compound & $\begin{array}{c}\text { Total Energy } \\
(\mathrm{Ha})\end{array}$ & $\begin{array}{c}\text { Binding Energy } \\
(\mathrm{Ha})\end{array}$ & $\begin{array}{c}\text { Dipole moment } \\
(\text { debye })\end{array}$ & $\begin{array}{c}\text { HOMO } \\
(\mathrm{eV})\end{array}$ & $\begin{array}{c}\text { LUMO } \\
(\mathrm{eV})\end{array}$ \\
\hline $\mathbf{1}$ & -1254.429809 & -8.3941386 & 3.8916 & -5.523 & -3.075 \\
\hline $\mathbf{2}$ & -2556.664661 & -9.4867640 & 4.2017 & -6.265 & -3.661 \\
\hline $\mathbf{3}$ & -2373.548254 & -9.3038517 & 7.0691 & -4.463 & -3.518 \\
\hline $\mathbf{4}$ & -1726.739102 & -10.3842915 & 1.1535 & -4.169 & -3.421 \\
\hline
\end{tabular}

1. The negative values of $\mathrm{E}_{\text {номо }}$ and $\mathrm{E}_{\mathrm{LUMO}}$ indicated the stability of prepared complexes (Figure 1).

2. The lower values of $\mathrm{E}_{\text {Номо }}$ indicated the molecule donating electron ability is small. On opposing, the larger $\mathrm{E}_{\text {номо }}$ suggested that the molecule is a good electron donor.

3. The binding energy of complexes was greater than free ligand that showed agreat the stability of the complexes.

4. The ligand exhibited higher value of dipole moment than prepared complexes that enhanced the potent activities of the free ligands.
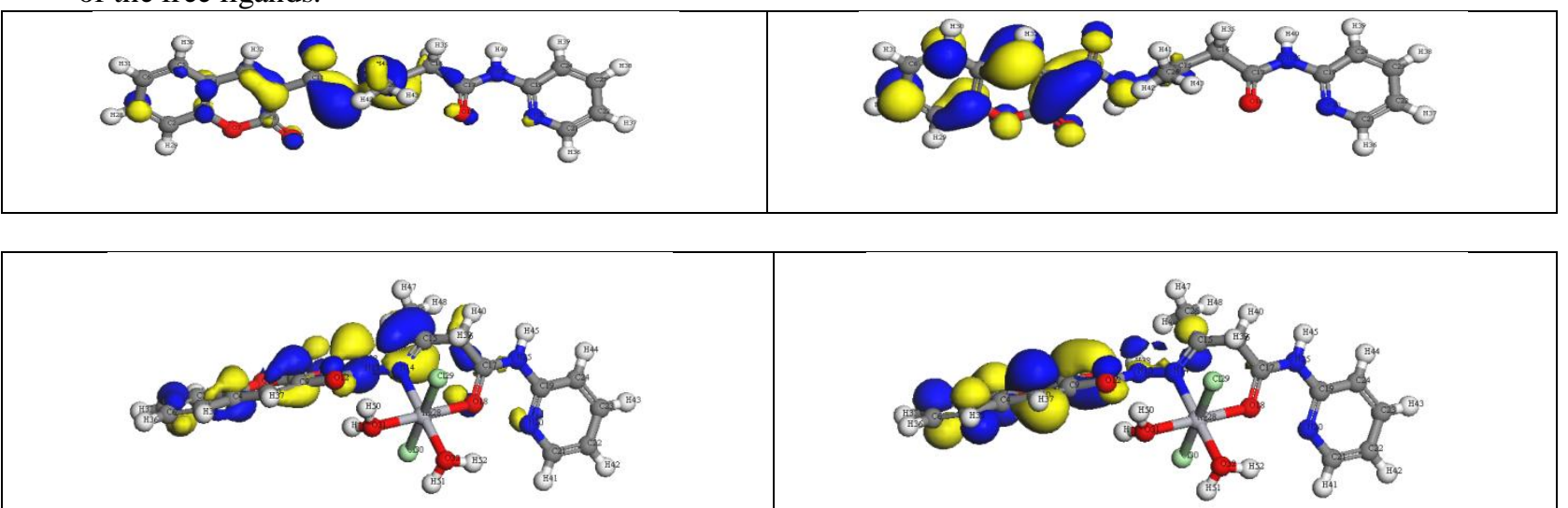

(B)
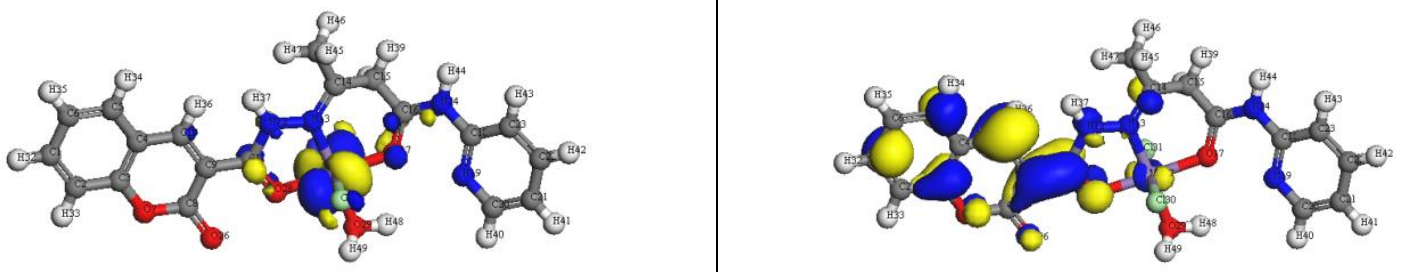

(C) 


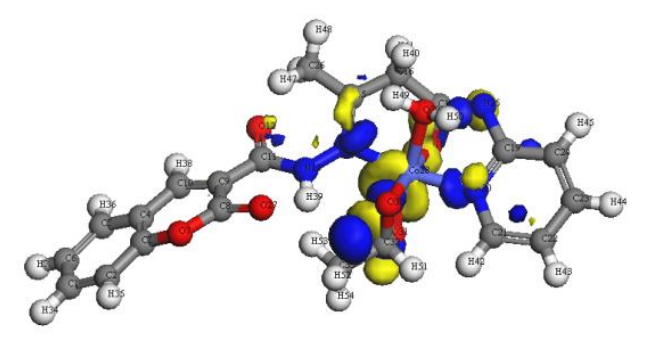

(D)

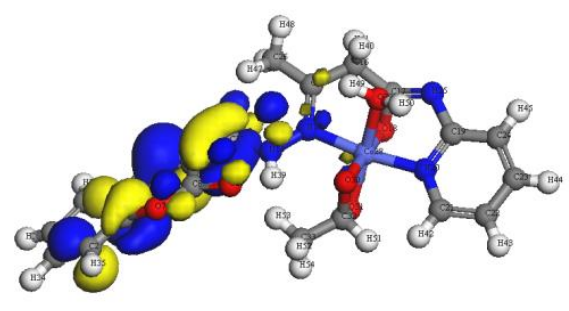

Fig. 1:- The HOMO and LUMO of (A) $\mathrm{H}_{2} \mathrm{~L},(\mathrm{~B})\left[\mathrm{Hg}\left(\mathrm{H}_{2} \mathrm{~L}\right)\left(\mathrm{H}_{2} \mathrm{O}\right)_{2} \mathrm{Cl}_{2}\right]$, (C) $\left[\mathrm{Mn}\left(\mathrm{H}_{2} \mathrm{~L}\right)\left(\mathrm{H}_{2} \mathrm{O}\right) \mathrm{Cl}_{2}\right]$,

(D) $\left[\mathrm{Co}(\mathrm{HL})(\mathrm{OAc})\left(\mathrm{H}_{2} \mathrm{O}\right)\right] \cdot 2 \mathrm{H}_{2} \mathrm{O}$

\section{Molecular electrostatic potential (MEP) of $\mathrm{H}_{2} \mathrm{~L}:-$}

The MEP was reflected a good descriptor sites for nucleophilic and electrophilic attack [41]. In the current study, 3D plots of MEP were drawn for the ligand and their metal complexes (Figure 2). From the MEP, the electron-rich area has red colour (favour site for electrophilic attack). However, the electron-poor area has blue colour (favour site for nucleophilic attack) [42]. But, the green area indicated to the neutral electrostatic potential region.

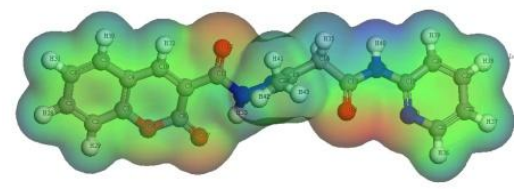

(A)

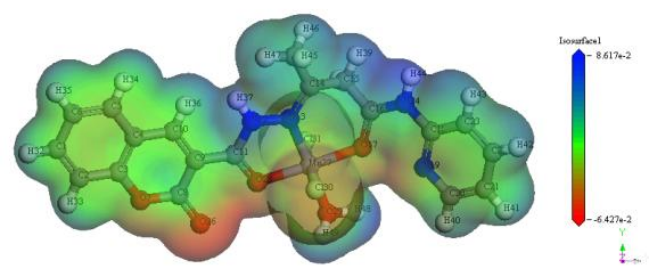

(C)

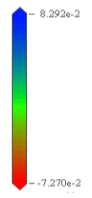$$
\$
$$

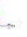

-

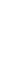

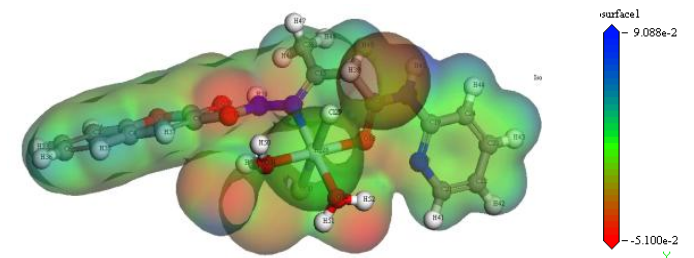

(B)

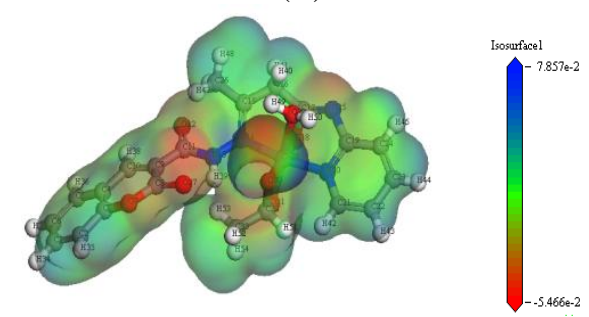

(D)

Fig. 2:p Molecular electrostatic potential map for (A) $\mathrm{H}_{2} \mathrm{~L}$, (B) $\left[\mathrm{Hg}\left(\mathrm{H}_{2} \mathrm{~L}\right)\left(\mathrm{H}_{2} \mathrm{O}\right)_{2} \mathrm{Cl}_{2}\right]$, (C) $\left[\mathrm{Mn}\left(\mathrm{H}_{2} \mathrm{~L}\right)\left(\mathrm{H}_{2} \mathrm{O}\right) \mathrm{Cl}_{2}\right]$, (D) $\left[\mathrm{Co}(\mathrm{HL})(\mathrm{OAc})\left(\mathrm{H}_{2} \mathrm{O}\right)\right] \cdot 2 \mathrm{H}_{2} \mathrm{O}$.

\section{Biological activity:-}

The biological activity of Coumarin derivatives was encouraged us to assume systematic studies on their complexation affinity and test their abilities beside economically vital fungal and bacteria [43,44].

\section{Antifungal activity:-}

The results revealed that the ligand and its metal complexes have an important activity against Aspergillus flavus and Candida albicans (Table 4). The $\mathrm{H}_{2} \mathrm{~L}$ and $\mathrm{Mn}$ (II) complex are more potent against Aspergillus flavus than Candida albicans in comparison with the standard drug Fluconazole [45].

\section{Antibacterial activity:-}

The investigated compounds along with Ciprofloxacin (standard drug) and DMSO (solvent control) were screened individually for their antibacterial activity [46-48]. The activity of the tested compounds was matched to the activity of Ciprofmloxacin as a standard antibiotic. The MIC values showed that $\mathrm{H}_{2} \mathrm{~L}$ and $\mathrm{Mn}(\mathrm{II})$ complex have the highest antibacterial activity (Table 4). 
Table 4. Antibacterial and antifungal activities in terms of MIC $(\mu \mathrm{g} / \mathrm{mL})$

\begin{tabular}{|l|c|c|c|c|c|c|}
\hline Compound & E. coli & P. aeuroginosa & S. aureus & B. subtilis & C. Albicans & A. flavus \\
\hline Ciprofloxacin & 1.56 & 0.78 & 1.56 & 0.39 & - & - \\
\hline Fluconazole & - & - & - & - & 1.56 & 0.78 \\
\hline 1 & 1.17 & 0.58 & 1.17 & 0.78 & 1.56 & 1.17 \\
\hline 2 & 37.5 & 25 & 9.37 & 4.68 & 12.5 & 6.25 \\
\hline 3 & 1.56 & 0.78 & 1.17 & 0.58 & 2.34 & 1.56 \\
\hline 4 & $>100$ & 50 & 25 & 18.75 & 37.5 & 25 \\
\hline
\end{tabular}

The antioxidant activity of ligands and their metal complexes:-

The antioxidant activity of the tested compounds was estimated using ABTS assay [49]. All tested compounds have low antioxidant activity except $\mathrm{H}_{2} \mathrm{~L}$ and $\mathrm{Mn}$ (II) complex demonstrated the maximum antioxidant activity in comparison with standard ascorbic-acid. Additionally, the anti-oxidant activity of tested compounds was established for erythrocyte hemolysis. All the tested compounds demonstrated weak anti-oxidative activity in the hemolysis assay, but Mn(II) complex has well effects (Table 5, 6).

Table 5:- Anti-oxidant assays by ABTS method

\begin{tabular}{|l|c|c|}
\hline Method & \multicolumn{2}{|c|}{ ABTS } \\
& Abs(control)-Abs(test)/Abs(control)x100 \\
\hline Compounds & Absorbance of samples & $\%$ inhibition \\
\hline Control of ABTS & 0.510 & $0 \%$ \\
\hline Ascorbic-acid & 0.055 & $89.2 \%$ \\
\hline 1 & 0.077 & $84.9 \%$ \\
\hline 2 & 0.223 & $56.3 \%$ \\
\hline 3 & 0.078 & $84.7 \%$ \\
\hline 4 & 0.245 & $52.0 \%$ \\
\hline
\end{tabular}

Table 6:- Anti-oxidant assays by erythrocyte hemolysis

\begin{tabular}{|l|c|c|}
\hline \multirow{2}{*}{ Compounds } & \multicolumn{2}{|c|}{ Erythrocyte hemolysis } \\
\cline { 2 - 3 } & A/B x 100 \\
\hline Absorbance of $\mathrm{H}_{2} \mathrm{O}(\mathrm{B})$ & 0.896 & \% hemolysis \\
\hline Ascorbic-acid & 0.042 & --- \\
\hline 1 & 0.116 & $4.7 \%$ \\
\hline 2 & 0.395 & $12.9 \%$ \\
\hline 3 & 0.089 & $44.1 \%$ \\
\hline 4 & 0.389 & $9.9 \%$ \\
\hline
\end{tabular}

The cytotoxicity of $\mathrm{H}_{2} \mathrm{~L}$ and its metal complexes on HCT-116 cell line:-

The cytotoxicity examine of the investigated compounds against human colorectal carcinoma cells lines (HCT) were demonstrated in Table 7. The data detected that the ligand (IC50 $=4.8 \mu \mathrm{g} / \mathrm{ml}$ ) and $\mathrm{Mn}$ (II) complex (IC50 $=5.5$ $\mu \mathrm{g} / \mathrm{ml}$ ) were established a greatly inhibitory effect than the other tested compounds. Conversely, Co(II) complex has greater IC50 value ( $47.8 \mu \mathrm{g} / \mathrm{ml}$ ) revealed almost no activity [50].

Table 7:- Cytotoxicity (IC50) of tested compounds on HCT-116 cell line.

\begin{tabular}{|c|c|}
\hline Compounds & In vitro Cytotoxicity IC50 $(\mu \mathrm{g} / \mathrm{ml})$ \\
\hline $5 \mathrm{FU}$ & 5.2 \\
\hline 1 & 4.8 \\
\hline 2 & 25.7 \\
\hline 3 & 5.5 \\
\hline 4 & 47.8 \\
\hline
\end{tabular}




\section{Ion-flotation separation:-}

Influence of initial pH:-

The effect of initial $\mathrm{pH}$ were performed on the floatability of metal ions $\left(2 \times 10^{-4} \mathrm{~mol} . \mathrm{L}^{-1}\right)$ using $1 \times 10^{-3} \mathrm{~mol} . \mathrm{L}^{-1}$ of HOL and $2 \times 10^{-4}$ mol. $\mathrm{L}^{-1}$ of $\mathrm{H}_{2} \mathrm{~L}$. The results showed that, the maximum floatability were reached in the $\mathrm{pH}$ range (610) for $\mathrm{Pb}^{2+}$ and (5-10) for $\mathrm{Cd}^{2+}$ ions (Figure 3). This enables the use of the $\mathrm{H}_{2} \mathrm{~L}$ for the separation of metal ions from different media.

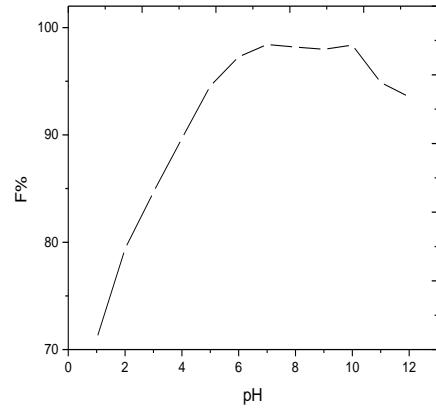

$\mathrm{Cd}^{2+}$

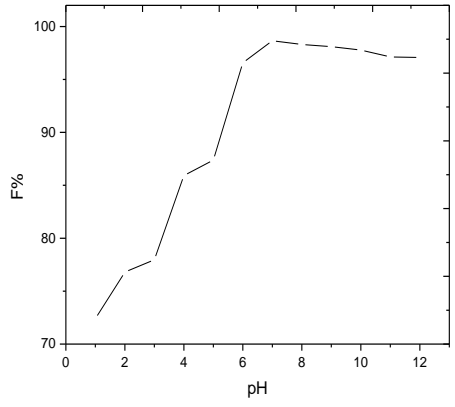

$\mathrm{Pb}^{2+}$

Fig. 3:- Influence of $\mathrm{pH}$ on the floatability of $2 \times 10^{-4}$ mol. $\mathrm{L}^{-1} \mathrm{Cd}^{2+}$ and $\mathrm{Pb}^{2+}$ ions using $2 \times 10^{-4} \mathrm{~mol}^{-\mathrm{L}^{-1}}$ of ligand and $1 \times 10^{-3}$ mol. $\mathrm{L}^{-1} \mathrm{HOL}$.

Influence of initial metal concentration:-

Attempts to float various concentrations of $\mathrm{Cd}^{2+}$ and $\mathrm{Pb}^{2+}$ ions using $2 \times 10^{-4}$ mol. $\mathrm{L}^{-1}$ of $\mathrm{H}_{2} \mathrm{~L}$ and $1 \times 10^{-3}$ mol. $\mathrm{L}^{-1} \mathrm{HOL}$ at $\mathrm{pH} \sim 7$ were carried out. The results displayed that the maximum flotation efficiency $(\sim 100 \%)$ of $\mathrm{Cd}^{2+}$ and $\mathrm{Pb}^{2+}$ ions was achieved and rested constant for the $\mathrm{H}_{2} \mathrm{~L}$ whenever the ratio of $\mathrm{M}: \mathrm{L}$ is (1:1) (Figure 4).The chelating agent presented quantitative separation of $\mathrm{Cd}^{2+}$ and $\mathrm{Pb}^{2+}$ ions $(\sim 100 \%)$ which attributed to the presence of sufficient quantities of $\mathrm{H}_{2} \mathrm{~L}$ to bind all $\mathrm{Cd}^{2+}$ and $\mathrm{Pb}^{2+}$ ions.

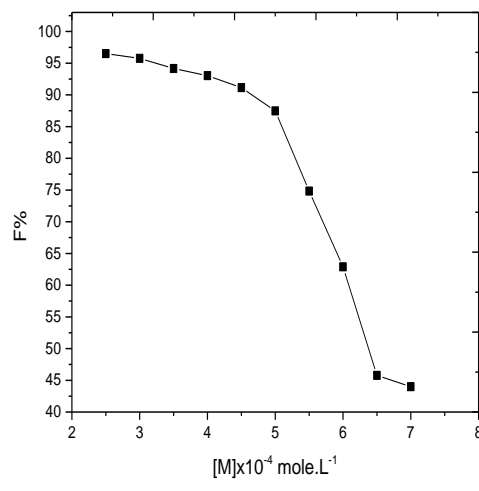

$\mathrm{Cd}^{2+}$

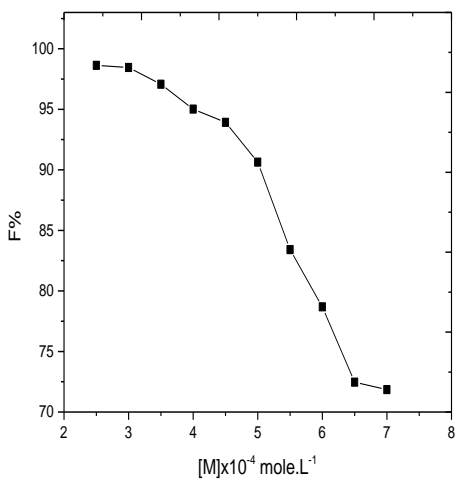

$\mathrm{Pb}^{2+}$

Fig. 4:- Floatability of different concentrations of $\mathrm{Cd}^{2+}$ and $\mathrm{Pb}^{2+}$ ions using $2 \times 10^{-4}$ mol. $\mathrm{L}^{-1}$ of prepared ligand and

\section{Influence of ligand concentration:-}

$$
1 \times 10^{-3} \mathrm{~mol} . \mathrm{L}^{-1} \mathrm{HOL} \text { at } \mathrm{pH} \sim 7
$$

The collecting ability of $\mathrm{H}_{2} \mathrm{~L}$ to $\mathrm{Cd}^{2+}$ and $\mathrm{Pb}^{2+}$ ions was experienced using $1 \times 10^{-3}$ mol.L $\mathrm{L}^{-1} \mathrm{HOL}$ at $\mathrm{pH} \sim 7$. The outcomes data showed that, the floatability of $\mathrm{Cd}^{2+}$ and $\mathrm{Pb}^{2+}$ ions increases sharply reaching its maximum value $(\sim 100 \%)$ at $\mathrm{M}: \mathrm{L}$ ratio of (1:1) (Figure 5). Additional $\mathrm{H}_{2} \mathrm{~L}$ has no opposing effect on the flotation method, therefore $2 \times 10^{-4}$ mol. $\mathrm{L}^{-1}$ of $\mathrm{H}_{2} \mathrm{~L}$ was used throughout. 


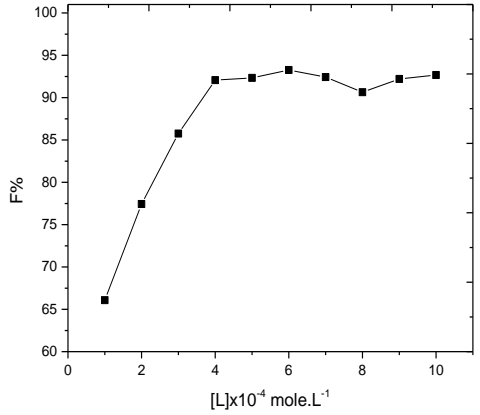

$\mathrm{Cd}^{2+}$

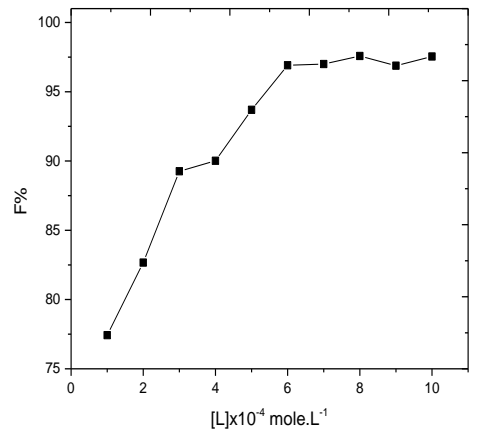

$\mathrm{Pb}^{2+}$

Fig. 5:- Floatability of $2 \times 10^{-4} \mathrm{~mol} \cdot \mathrm{L}^{-1} \mathrm{Cd}^{2+}$ and $\mathrm{Pb}^{2+}$ ions using different concentrations of prepared ligand and $1 \times 10^{-3} \mathrm{~mol} . \mathrm{L}^{-1} \mathrm{HOL}$ at $\mathrm{pH} \sim 7$

1.1.1. Influence of surfactant concentration

Trials were accepted to float $\mathrm{Cd}^{2+}$ and $\mathrm{Pb}^{2+}$ ions with $\mathrm{HOL}$ alone, however the recovery did not exceed $27.5 \%$. Hence, further experiments were done to float $2 \times 10^{-4}$ mol. $\mathrm{L}^{-1} \mathrm{Cd}^{2+}$ and $\mathrm{Pb}^{2+}$ ions in the existence of $2 \times 10^{-4}$ mol. $\mathrm{L}^{-1}$ of $\mathrm{H}_{2} \mathrm{~L}$ and various concentrations of HOL $\left(1 \times 10^{-3}-5 \times 10^{-2} \mathrm{~mol}^{-\mathrm{L}^{-1}}\right)$ at $\mathrm{pH} \sim 7$. The outcomes data showed that the HOL concentration in $1 \times 10^{-3}-9 \times 10^{-3}$ mol. $\mathrm{L}^{-1}$ range, high floatation $\%$ of $\mathrm{Cd}^{2+}$ and $\mathrm{Pb}^{2+}$ was reached (Figure 6). The partial separation of $\mathrm{Cd}^{2+}$ or $\mathrm{Pb}^{2+}$ ions at larger surfactant concentration assignable to the fact that the surfactant improved the particles state, $\mathrm{Cd}^{2+}$ and $\mathrm{Pb}^{2+}$ ligand precipitates, from coagulation precipitation via coagulation flotation to re-dispersion with an increase in the added amount of HOL [51]. Moreover, at great surfactant concentration, poor flotation was observed because of the formation a stable hydrate micelle coating on the solid surface or, by forming hydrated envelope of surfactant on the air bubble surface [52, 53].

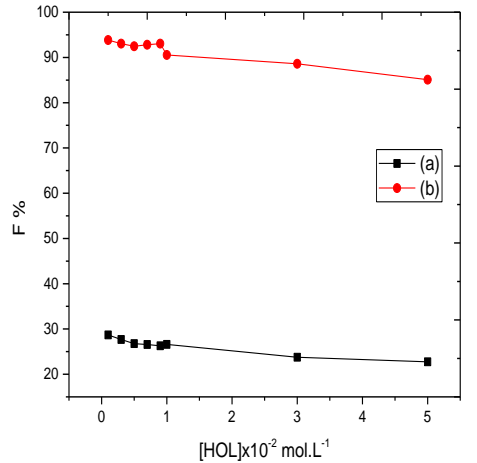

$\mathrm{Cd}^{2+}$

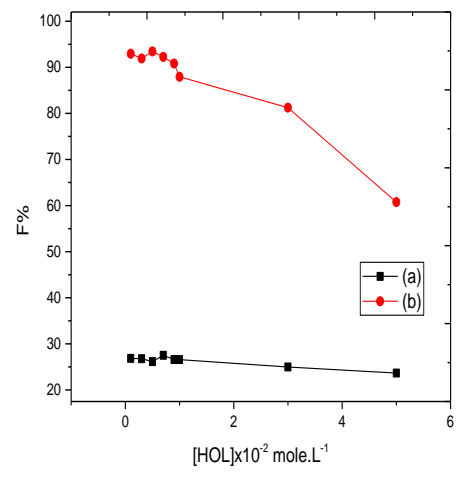

$\mathrm{Pb}^{2+}$

Fig. 6. Floatability of $2 \times 10^{-4}$ mol. $\mathrm{L}^{-1} \mathrm{Cd}^{2+}$ and $\mathrm{Pb}^{2+}$ ions using different concentrations of $\mathrm{HOL}$ in the absence (a) and presence (b) of $2 \times 10^{-4}$ mol. $\mathrm{L}^{-1}$ of prepared ligand at $\mathrm{pH} \sim 7$

\section{Influence of temperature:-}

The Mixture containing $\mathrm{Cd}^{2+}$ or $\mathrm{Pb}^{2+}$ ions, $\mathrm{H}_{2} \mathrm{~L}$ and other solution involving $\mathrm{HOL}$ were either heated in a water bath or cooled in an ice bath at the identical temperature. The $\mathrm{HOL}$ solution was rapidly poured into $\mathrm{Cd}^{2+}$ or $\mathrm{Pb}^{2+}$ ions solution. The mixture was bring together to the flotation cell. The outcome data shown the maximum flotation $(\sim 100 \%)$ of $\mathrm{Cd}^{2+}$ and $\mathrm{Pb}^{2+}$ ions lie in $15-80^{\circ} \mathrm{C}$ range (Figure 7). The decrease in separation by increasing temperature more than $80^{\circ} \mathrm{C}$ due to the solubility of the precipitate increase and the instability of the foam giving rise to partial dissolution of the precipitate and insufficient foam constancy to delay the precipitate [54]. 


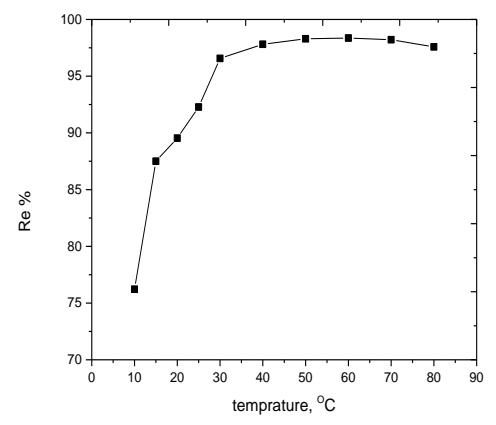

$\mathrm{Cd}^{2+}$

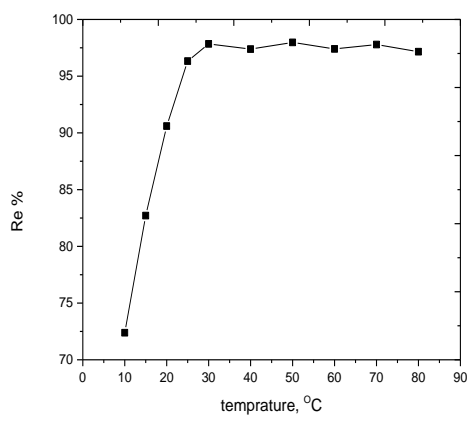

$\mathrm{Pb}^{2+}$

Fig. 7:- Floatability of $2 \times 10^{-4}$ mol. $\mathrm{L}^{-1} \mathrm{Cd}^{2+}$ and $\mathrm{Pb}^{2+}$ ions at different temperatures using $2 \times 10^{-4} \mathrm{~mol} . \mathrm{L}^{-1}$ of prepared ligand and $1 \times 10^{-3} \mathrm{~mol} \cdot \mathrm{L}^{-1} \mathrm{HOL}$ at $\mathrm{pH} \sim 7$

\section{Effect of presence of foreign ions}

The percentage of removal of $\mathrm{Cd}^{2+}$ and $\mathrm{Pb}^{2+}$ ions from a solution of $\mathrm{pH} 7$ containing $30 \mathrm{mg} \cdot \mathrm{L}^{-1}$ of $\mathrm{H}_{2} \mathrm{~L}$ was performed in the existence of high concentrations of different cations and anions. The anions used as chlorides while, the cations used as $\mathrm{Na}^{+}$or $\mathrm{K}^{+}$salts. The suitable quantities for each ion, giving an error $( \pm 4 \%)$ in the removal efficiency of $\mathrm{Cd}^{2+}$ and $\mathrm{Pb}^{2+}$ ions (Table 8). The data indicated that all the foreign ions with comparatively high concentrations have no opposite effect on the flotation of $\mathrm{Cd}^{2+}$ and $\mathrm{Pb}^{2+}$.

Table 8:- Effects of the foreign ions on the removal percentage of the examined metal ions

\begin{tabular}{|l|c|c|c|}
\hline Ion & Interference/analyte ratio $\left(\mathrm{mg} \mathrm{L}^{-1}\right)$ & $\mathrm{Re} \% \mathrm{Cd}(\mathrm{II})$ & $\mathrm{Re} \% \mathrm{~Pb}(\mathrm{II})$ \\
\hline $\mathrm{Na}^{+}$ & 35 & 97.2 & 97.8 \\
\hline $\mathrm{K}^{+}$ & 35 & 98.8 & 99.8 \\
\hline $\mathrm{Mg}^{2+}$ & 25 & 96.6 & 98.3 \\
\hline $\mathrm{Ca}^{2+}$ & 20 & 94.3 & 95.7 \\
\hline $\mathrm{Cl}^{-}$ & 35 & 95.7 & 96.9 \\
\hline $\mathrm{SO}_{4}{ }^{2-}$ & 35 & 97.9 & 97.1 \\
\hline $\mathrm{HCO}_{3}^{-}$ & 15 & 99.5 & 96.4 \\
\hline $\mathrm{CH}_{3} \mathrm{COO}^{-}$ & 30 & 95.4 & 98.1 \\
\hline
\end{tabular}

$\left[\mathrm{M}=2 \times 10^{-4}\right.$ mol. $\mathrm{L}^{-1} ;$ Ligand $\left.=2 \times 10^{-4} \mathrm{~mol} . \mathrm{L}^{-1} ; \mathrm{HOL}=1 \times 10^{-3} \mathrm{~mol} . \mathrm{L}^{-1} ; \mathrm{pH}=7\right]$

\section{Application:-}

Numeral of experiments were done to study the applicability of the proposed method of recover $\mathrm{Cd}^{2+}$ and $\mathrm{Pb}^{2+}$ ions spiked to $1 \mathrm{~L}$ of aqueous samples. The flotation experiments were done at $\mathrm{pH} 7$ using $50 \mathrm{~mL}$ filtered sample solutions. The outcomes data shown that the recovery was acceptable and measureable under the suggested conditions of the applied flotation method (Table 9).

Table 9:- Recovery of studied metal ions from some water samples

\begin{tabular}{|c|c|c|c|c|}
\hline Water samples (location) & \multicolumn{2}{|c|}{$\mathrm{Cd}^{2+}$} & \multicolumn{2}{c|}{$\mathrm{Pb}^{2+}$} \\
\cline { 2 - 5 } & Added metal $\left(\mathrm{mg} . \mathrm{L}^{-1}\right)$ & $\mathrm{Re} \%$ & Added metal $\left(\mathrm{mg} . \mathrm{L}^{-1}\right)$ & $\mathrm{Re} \%$ \\
\hline Mansoura & 10.15 & 87.49 & 15 & 92.47 \\
\hline Bilqas & 10.15 & 89.18 & 15 & 93.20 \\
\hline Alexandria & 10.15 & 87.54 & 15 & 92.92 \\
\hline Sharm El-Shiekh & 10.15 & 84.32 & 15 & 95.10 \\
\hline
\end{tabular}

[Ligand $=2 \times 10^{-4}$ mol. $\left.\mathrm{L}^{-1} ; \mathrm{HOL}=1 \times 10^{-3} \mathrm{~mol} . \mathrm{L}^{-1} ; \mathrm{pH}=\sim 7\right]$

Proposed flotation mechanism:-

The flotation mechanism of analyte-ligand precipitates was proposed depending on the following facts:

$\mathrm{Cd}^{2+}$ and $\mathrm{Pb}^{2+}$ ions reacted with $\mathrm{H}_{2} \mathrm{~L}$ in a $\mathrm{M}$ : $\mathrm{L}$ ratio of $(1: 1)$ to produce the $\mathrm{M}_{2} \mathrm{~L}$ complex consistent with this equation:

$$
\mathrm{M}^{2+}+\mathrm{H}_{2} \mathrm{~L}=\mathrm{M}_{2} \mathrm{~L}+2 \mathrm{H}^{+}
$$

$\mathrm{H}_{2} \mathrm{~L}$ has several electronegative atoms such as nitrogen and oxygen in the form of $\mathrm{C}=\mathrm{N}, \mathrm{C}=\mathrm{O}$ and $\mathrm{NH}$ functional groups that can form hydrogen bonds. 
The oleic acid began to dissociate at $\mathrm{pH}>5.2$ [54] and the $\%$ of different forms of HOL were detected by IR analysis (Table 10). The IR spectra of oleic acid with changing $\mathrm{pH}$ indicated that at $1300-1800 \mathrm{~cm}^{-1}$, there are significant bands of $\mathrm{COOH}, \mathrm{COO}^{-}$and $\mathrm{COO}^{-} \mathrm{Na}^{+}$[55]. These results agree with those reported [56] where, the $\mathrm{C}=\mathrm{O}$ stretching band of oleic acid at $1705 \mathrm{~cm}^{-1}$ is shifted on ionization to bands in $1520-1540 \mathrm{~cm}^{-1}$ range for sodium oleate. Thus, oleic acid can performance together with other structures, via hydrogen bonding, either in ( $\mathrm{R}-\mathrm{COOH})$ or $\left(\mathrm{R}_{-} \mathrm{COO}^{-}\right)$forms depending on the $\mathrm{pH}$ of the medium and agreeing with the following:

$$
\begin{aligned}
& \mathrm{R}-\mathrm{COOH}+\mathrm{M}_{2} \mathrm{~L}=\mathrm{R}-\mathrm{COOH} . \ldots \mathrm{LM}_{2} \\
& \mathrm{R}-\mathrm{COO}^{-}+\mathrm{M}_{2} \mathrm{~L}=\mathrm{R}-\mathrm{COO}^{-} \ldots . \mathrm{LM}_{2}
\end{aligned}
$$

The combination of oleic acid surfactant with the cadmium-ligand or lead-ligand chelate providing hydrophobic aggregates that float with the assistance of air bubbles to the solution surface [57].

\begin{tabular}{|c|c|c|c|c|}
\hline \multirow[b]{2}{*}{$\mathrm{pH}$} & \multicolumn{3}{|c|}{$(\%)$} & \multirow[t]{2}{*}{ Total } \\
\hline & HOL & $\mathrm{Ol}^{-}$ & $\mathrm{NaOL}$ & \\
\hline 5.2 & 100 & 0.0 & 0.0 & 100 \\
\hline 8.0 & 6.5 & 34.2 & 0.0 & 100 \\
\hline 8.2 & 38.5 & 57.7 & 3.8 & 100 \\
\hline 9.0 & 13.6 & 68.2 & 18.2 & 100 \\
\hline 11.5 & 0.0 & 80.0 & 20.0 & 100 \\
\hline 12.0 & 0.0 & 52.2 & 47.8 & 100 \\
\hline
\end{tabular}

Table 10:- Different forms of oleic acid determined by spectrophotometric.

\section{References:-}

1. Casley-Smith, J. R.; Morgan, R. G.; Piller, N. B. NEJM 1993, 329, 16, 1158-63.

2. Schäfer, F. P. Dye Lasers, 3rd ed.; Berlin' Springer-Verlag, 1990.

3. Duarte, F. J.; Hillman, L. W. Dye Laser Principles; Academic press: New York, 1990.

4. Duarte, F. J. Tunable Laser Optics; Elsevier-Academic: New York, 2003.

5. Corey, E. J.; Enders, D. Chemische. Berichte. 1978, 111, 1337-1361. doi:10.1002/cber.19781110413.

6. Ritter, J. K.; Chen, F.; Sheen, Y. Y.; Tran, H. M.; Kimura, S.; Yeatman M. T.; Owens I. S. J Biol Chem. 1992, 267, 5, 3257-61.

7. Link, K. P. Circulation 1959, 19, 97-107. doi:10.1161/01.CIR.19.1.97.

8. Liu, H. Extraction and Isolation of Compounds from Herbal Medicines. In: Willow, J. and Liu, H. Traditional Herbal Medicine Research Methods. John Wiley and Sons, Inc. 2011.

9. Farinola, N.; Piller, N. LYMPHATIC RESEARCH AND BIOLOGY 2005, 3, 2, 81-86. doi:10.1089/lrb.2005.3.81.

10. International Programme on Chemical Safety. "Brodifacoum (pesticide data sheet)". Retrieved 2006-12-14

11. Laposata, M.; Van Cott, E. M.; Lev, M. H. N Engl J Med. 2007. 356, 2, 174-82.

12. Bye, A.; King, H. K. Biochemical Journal 1970, 117, 237-45.

13. Montagner, C.; De Souza, S. M.; Groposoa, C.; Delle Monache, F.; Smânia, E. F.; Smânia Jr. A. Zeitschrift für Naturforschung 2008, C 63, (1-2), 21-8.

14. Weber, U. S.; Steffen, B; Siegers, C. P. Europe PMC 1998, 99, 2, 193-206.

15. Oliveira, P.F.M.; Baron, M.; Chamayou, A.; André-Barrès, C.; Guidetti, B.; Baltas, M. RSC Adv. $2014,4,100$. doi:10.1039/c4ra10489g.56736-56742.

16. Ibrahim, K.; Zaky, R.; Gomaa, E.; El-Hady, M. Research Journal of Pharmaceutical, Biological and Chemical Sciences 2011, 2, 3, 391-404.

17. Ibrahim, K.; Zaky, R.; Gomaa, E.; El-Hady, M. Anaele Universitatii din Bucuresti 2011, $20,149-154$.

18. El-Hady, M.; Zaky, R.; Ibrahim, K.; Gomaa, E. Journal of Molecular Structure 2012, 1016, 169-180.

19. Ibrahim, K.; Gomaa, E.; Zaky, R.; El-Hady, M. American Journal of Chemistry 2012, 2, 2, 23-26.

20. Ibrahim, K.; Zaky, R.; Gomaa, E.; El-Hady, M. Spectrochimica Acta Part A 2013, 107, $133-144$.

21. Delley, B. Phys Rev. 2002, 65, 85403-8509.

22. Modeling and Simulation Solutions for Chemicals and Materials Research, Materials Studio (Version 5.0), Accelrys software Inc., San Diego, USA. Available online at: www.accelrys.com 2009.

23. Hehre, W. J.; Radom, L.; Schlyer, P. V. R.; Pople, J. A. Ab Initio Molecular Orbital Theory, Wiley, New York 1986.

24. Kessi, A.; Delley, B. International Journal of Quantum Chemistry 1998, 68, 135-144. 
25. Hammer, B.; Hansen, L. B.; Nørskov, J. K. Phys. Rev. B 1999, 59, 7413-7421.

26. Matveev, A.; Staufer, M.; Mayer, M.; Rösch, N. Int. J. Quantum Chem 1999, 75,863-873.

27. Hawkey, P. M.; Lewis, D. A.; Oxford University Press: United Kingdom, 1994, 181-194.

28. Mosmann, T. Journal of lmmunological Methods 1983, 65, 55-63.

29. Lissi, E.; Modak, B.;Torres, R.; Escobar, J.; Urzua, A. Free Radical Res 1999, 30, 471-477.

30. El-Gazzar, A.; Youssef, M.; Youssef, A.; Abu-Hashem, A.; Badria, F. Eur J Med Chem 2009, 44, 609-624.

31. Aeschlach, R.; Loliger, J.; Scott, C.; Murcia, A.; Butler, J.; Halliwell, B.; Aruoma, I. Food Chem. Toxicol 1994, 32, 31-36.

32. Denizot, F.; Lang, R. J. Immunol. Methods 1986, 89, 271-277.

33. Mauceri, H.; Hanna, N.; Beckett, M.; Gorski, D.; Staba, M.; Stellato, K.; Bigelow, K.; Heimann, R.; Gately, S.; Dhanabal, M.; Soff, G.; Sukhatme, V.; Kufe, D.; Weichselbaum, R . Nature 1998, 394, $287-291$. doi: 10.1038/28412.

34. Morimoto, Y.; Tanaka, K.; Iwakiri, Y.; Tokuhiro, S.; Fukushima, S.; Takeuchi, Y. Biol. Pharm Bull 1995, 18, 417-1422.

35. Ibrahim, K.; Gabr, I.; Abu El-Reash, G.; Zaky, R. Monatsh Chem 2009, 140, 625-632. doi: 10.1007/s00706009-0106-x.

36. Ibrahim, K.; Zaky, K.; Gomma, E.; El-Hady, M. Res J Pharm Biol Chem Sci 2011, 2, 391-404.

37. Pretsch, E.; Bühlmann, P.; Badertscher, M. 4th; Berlin: Heidelberg, 2009.

38. Zaky, R.; Yousef, T. Journal of Molecular Structure 2011, 1002, 76-85.

39. Zaky, R. Taylor \& Francis Group, LLC 2011, 186, 365-380. doi:10.1080/10426507.2010.503207

40. Cotton, F. A.; Wilkinson, G.; Murillo, C. A.; Bochmann, M. Advanced Inorganic Chemistry, 6th ed., John Wiley \& Sons Inc. 2003.

41. Zalaoglu, Y.; Ulgen, A.; Terzioglu, C.; Yildirim, G. Fen Bilimleri Dergisi 2010, 14, 66-76.

42. Tanak, H.; Köysal, Y.; Işık, Ş.; Yaman, H.; Ahsen, V. Bull. Korean Chem 2011, 32, 673-680.

43. Filipović, N.; Borrmann, H.; Todorović, T.; Borna, M.; Spasojević, V.; Sladić, D.; Novaković, I.; Andjelković, A. Inorganica Chimica Acta 2009, 362, 1996-2000.

44. Thimmaiah, N.; Chandrappa, T.; Jayarama, R. Polyhedron 1984, 3, 1237-1239. doi:10.1016/S02775387(00)84669-0.

45. Nagar, R. Journal of Inorganic Biochemistry 1990, 40, 349-356.

46. Johari, R. B.; Sharma, R. C. J Indian Chem Soc. 1988, 65, 793-794.

47. Abd El-Wahab, Z.; El-Sarrag, M. Spectrochimica Acta A 2004, 60, 271-277.

48. Panchal, P.; Parekh, H.; Patel, M.; Toxicol. Environ. Chem 2005, 87, 313-320.

49. Kostova, I.; Saso, C. Curr. Med. Chem 2013, 20, 4609-4632.

50. Yousef, A.; Badria, F.; Ghazy, S.; El-Gammal, O.; Abu El-Reash, G. Medicine and Medical Sci $2011,3,37-46$.

51. Ghazy, S. E.; Samra, S. E.; Mahdy, A. M.; El-Morsy, S. M. Anal. Sci. 2006, 22, 377-382.

52. Klassen, V. I.; Mokrousov, V. A.; Butterworths: London 1963.

53. Ghazy, S. E.; Mostafa, G. A. Bull. Chem. Soc. Jpn. 2001, 74, 1273-1278.

54. Ghazy, S. E.; Kabil, M. A. Bull. Chem. Soc. Jpn. 1994, 67, 474-478.

55. Ghazy, S. E.; Rakha T. H.; El-Kady, E. M.; El-Asmy A. A. Indian J. Chem. Technol 2000, 7, $178-182$.

56. Pol'kin, S. I.; Berger, G. S.; Revazashavili, I. B.; Shchepkina, M. M. Izv. Vyssh. Ucheb. Zaved. Tsvet. Met 1968, 11, 6-11.

57. Ramachandra, R. S. Surface Chemistry of Froth Flotation, Vol. 2 Reagents and Mechanisms, 2nd ed.; Kluer Academic / Plenum Puplishers: 